\title{
Exploring Influence of Virtual Reality-Based English Learning Activities Towards Secondary Students' English Writing Achievement
}

\author{
Kevin Marion Sepang ${ }^{1}$ \\ Ganesha Education University, Indonesia \\ kevinsepang6@gmail.com \\ Made Hery Santosa ${ }^{2}$ \\ Ganesha Education University, Indonesia \\ mhsantosa@undiksha.ac.id \\ Gusti Ayu Putu Suprianti ${ }^{3}$ \\ Ganesha Education University, Indonesia \\ gap.suprianti@undiksha.ac.id
}

\begin{abstract}
The researcher conducted experimental research of using Virtual Reality as instructional media in form of Virtual Reality-based activities especially in learning English in form of writing skill. This research had two purposes, namely (1) to determine whether there is an effect of Virtual Reality-based English learning activities towards students' English learning achievement in a public secondary school in North Bali, (2) to find out how VR-based English learning activities affects students' English learning achievement in form of writing achievement. The research design used in this study was explanatory sequential explanatory mixed methods design. The population was first grade students of a public secondary school in North Bali. The result of qualitative data analysis showed that there is an effect of Virtual Reality-based English learning activities towards $10^{\text {th }}$ grade students' English learning achievement in public secondary school in North Bali. The Effect Size of this quantitative research is in range on low effect size. The result of qualitative data showed that there were strengths and weaknesses of using VR-based English learning activities that affects the result of quantitative data of the students' English learning achievement in a public secondary school in North Bali in form of writing skill.
\end{abstract}

Keywords: Virtual Reality, English Achievement, Learning Activities

\section{INTRODUCTION}

In the $21^{\text {st }}$ century, the growth of technology is really fast. This era made the improvement of the integrating Internet of Things and Services (IoTS) on industrial works is more valuable and more integrated. This new term of this integrating, digitized, and industrialized connection is called Industrial Revolution 4.0 (Müller, Kiel, \& Voigt, 2018). Noting on living in this digital era, human resource also should move forward in order to survive. Every human resource should prepare themselves in order to compete with others in this digitalized era. Furthermore, in Revolution Industry 4.0, human resource will face new techs and products. Thus, Human resource needs education and the education itself shout be reformed in order to enhance sensitivity, creativity and education (Park, 2017). The future human labor will take those challenges in Revolution Industry 
4.0 easily. This generation is called $Z$ generation or GenZ. This generation involves kids that were born between 1995 and later (Törőcsik, Szűcs, \& Kehl, 2014). This generation can meet the requirement to compete in Revolution Industry 4.0 because they were born with technology surrounds them (Santosa, 2017). They are already familiar with technologies and getting used to digital aspect. It helps them to reach rich information from different perspective and issues with very quick access.

In order to gain the Gen Z's interest on learning, especially in this era, the teachers should find a new way and method in order to get the students' interest in learning. The process of learning and teaching activities should be something new, innovative, enjoyable, fun and attractive in the classroom. One of the ways to reach that kind of learning and teaching activities strategy is by using innovative teaching media or instructional media. The teaching or instructional media in education also changed nowadays. The growth of technology affects the teaching media to new, emerging, innovative and attractive ways. One of them, Virtual Reality is one form of the evolution in teaching media (Piovesan, Passerino, \& Pereira, 2012).

The purpose of using teaching or instructional media is to help the students understand about the material and to reach the expectation of the teacher about the point of material that the student will get from the material. In further, in order to know about the progress of the students in learning both practice and theory, the teacher needs to assess them as learning achievement. In order to increase the students' learning achievement, the teacher should use an innovative teaching strategy by using emerging and innovative instructional media in order to get the Gen Z's interest of study. Because of that reason, the researcher tries to experiment of using Virtual Reality as instructional media in form of Virtual Reality-based activities especially in learning English. One of the possible ways with low budget version in conduction Virtual Reality-based English learning activities in school is by teaching English writing skill in form of descriptive text.

By those mean, Virtual Reality is beneficial for the students and introduces them to the future learning method and based on preliminary study, there is no school in North Bali that ever-used Virtual Reality-based English learning activities in teaching and learning process especially in teaching and learning English in the classroom. So, it is important to investigate the effect of Virtual Reality-based English learning activities towards the secondary students' English learning achievement in a public secondary school in North Bali.

Some previous studies have been conducted on this topic. One of them, a study by Dolgunsöz, Yıldırım, \& Yıldırım (2018) about the effect of using Virtual Reality on EFL writing performance showed that EFL students thought that VR technology is promising and motivating. They used Exploratory mixed method for this research. They found that VR is enjoyable and creating a feeling of involvement. Also, they found that for the student, Virtual reality is friendly user, ease in use, friendly interface and also comfortable elated to their limitation. They also stated that Virtual Reality also support the rentetion and the perfomance of writing skill in the long term in EFL classrooom. Moreover, from the studies above, this research has a similarity upon previous studies. That similarity is the variable of the research is the use of Virtual Reality. In addition, the previous studies also concern about the use of Virtual Reality as learning media to improve the students' learning achievement. 
This research had two purposes, namely (1) to determine whether there is an effect of Virtual Reality-based English learning activities towards students' English learning achievement in a public secondary school in North Bali, (2) to find out how VR-based English learning activities affects students' English learning achievement in form of writing achievement.

\section{RESEARCH METHOD}

This research is in form of mixed method design. According to Creswell (2014), mixed method research method design involves integration or merging of qualitative research and qualitative data in this method. In this method, the research intends to use this kind of method, quantitative and qualitative data to serve the best understanding and result of the research problem. Creswell (2014) stated that there are three main primary models of mixed method field in the social science now days. Since this research is emphasized on the effect of implementing Virtual Reality as learning media and it will be assessed qualitatively, the researcher used one of the main primary models of mixed method. That is explanatory sequential mixed method design. The researcher firstly analyzed the quantitative data and the result will be described further with the result of qualitative data. The qualitative data will support and provide indepth data for the result of quantitative data. If the result is negative, then there is no effect in this study.

The population of this study was 385 students from one of the schools from Buleleng district, Bali Province, Indonesia. The next step is to determine which group become the experimental group and control group. The researcher uses lottery system to determine it. The result, X MIA 5 becomes experimental group and X MIA 6 become control group. There are two kinds of instrument that researcher used for gathering the data. There are test and interview guide.

\section{FINDINGS AND DISCUSSION}

\section{The Effect of Virtual Reality-Based English Learning Activities Towards $10^{\text {th }}$ Grade Students' English Learning Achievement.}

The result of the post test was analyzed to find out the mean and Standard Deviation. The researcher may provide the data with a diagram.

Table 1. Comparison between experimental group and Control group

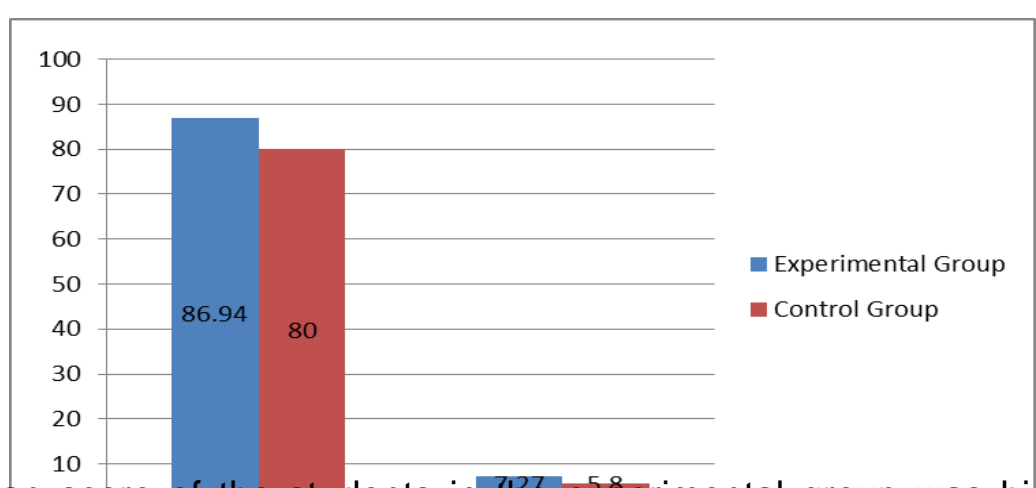

The mean score of the students in the experimental group was higher than the control group. The sean score ofstheexperimental group was 86.94 and the mean of control group was 80.00. It indicated that the different 
treatments given to the experimental group and control group had significant difference of the result of the mean. It could be seen that the mean score of the experimental group was higher than control group. It indicated that the students from experimental group had better performance than students from the control group in terms of learning achievement that achieved by the students.

Independent sample t-test (t-test) was conducted in order to know whether there was significant difference on the tenth-grade students' English learning achievement between students taught by using Virtual Reality-based English learning activity and by using conventional learning media. The results of the data were calculated by using SPSS 23 at $5 \%$ level of significance. Based on the SPSS 23's result, the value of sig. (2-tailed) was 0.000 . It indicates that the observed level of significant (sig. (2-tailed)) was less than alpha level $(\alpha=0.05)$. Since the value of (sig. (2-tailed)) was less than the standard alpha level $(0.000<0.05)$, then the null hypothesis was rejected $(\mathrm{H} 0)$ and alternative hypothesis $(\mathrm{H \alpha})$ was accepted. In accordance, with analysis presented, it could be concluded that there is an effect of using Virtual Reality-based learning on students' learning achievement in form of writing skills. It also proven by the higher mean score achieved by the students in experimental group than the in control group.

The researcher also conducted the effect size for this research to determine how important and how far the variable affects the subject. The researcher used Cohen's d and Eta Squared calculator to measure the Effect Size. Effect Size of this quantitative research from the Cohen's d is 1.055 and the $r$ is 0.4666 which is in range on low effect size. Based on the Effect Size table, the researcher may conclude that this quantitative research has effect on using Virtual reality towards 10th grade students' English learning achievement but has low effect or only affects a small scale of the experimental groups on students' English learning achievement in form of writing skill.

\section{The Ways of Virtual Reality-English Learning Based Activities Affects Learning Achievement Especially in Writing Skill}

In this section, the researcher discussed comprehensively about the ways of Virtual Reality-English Learning Based Activities Affects Learning Achievement Especially in Writing Skill in form of strengths and weaknesses in Using Virtual Reality-English Learning Activities in the Classroom.

The success of the experiment in using Virtual reality-Learning based is supported by the result of the students' interview about the ways of VR-based English learning activities affects their English learning achievement on writing skill in form of the strengths in using Virtual Reality-English learning activities in the classroom.

\section{Strengths Dimension in Using Virtual Reality in the Classroom}

The first the first factor is from the first dimension about their reason of interest in using VR as learning media is the students stated that they have positive reason of interest toward the use of VR in the classroom. All of them answered because that is new and authentic for them. Also, the way of researcher and the way they learn are new and never happened before. It made them more engaged in the classroom because they excited with the way they 
learned. They contacted and shared each other about what they see, how they feel and what they found on that video. They felt excited and more fun about how they learn in the class. It made them to engage more and explore further in learning because it is new to them. It engages the student to do more in doing task. So it is one of factor that affects the score of the students' learning achievement in this research.

"I felt something new. Something that never happened before in my learning processes. Like, we are excited about how we learn with a new way."

This finding is coherent with finding from Dong (2017). Dong stated that Virtual Reality attracted the people especially the student in the field of the education. VR classroom really helps the student to understand the contents and material in learning and also improve their experience in learning. Then, the second factor is from the dimension about the students' opinion in accessing Virtual Reality as learning media as Real-Life experience in learning English. The result is the students have positive answer in terms of "Real life" experience. They feel that it is different that learning from conventional media such as video and others. The students said that they can visit all place over the world without leaving the classroom and they feel like they were there while they played VR video. They experienced the immersive feel on VR video. They felt that they were on that video for example; they visited, watched and observed an erupting volcano.

"I feel that I was there. Like no other kinds of learning. We watched VR video like we were there. It is amazing. You know that we can look our surrounding $360^{\circ}$. That makes me excited."

This finding is also coherent with finding from Dong (2017). This researcher stated that by using Virtual Reality, it will change and move the way of the people think in term of senses and even transform the way of people think and understanding time and space especially in real-life context. Students also said that by using VR gear is so safe because they explore some sites outside the classroom without leaving the classroom. So, they can freely observe the place on VR video without worrying about the terrain and even hazard zone on the video. It is because they were not leaving the classroom but they can observe the place outside the classroom.

\footnotetext{
"It safe for me I think. It is because we only used our head movement to explore VR video. Also, we are not leaving in the classroom. Usually we need a tour to visit a place to describe accurately. Now with VR video, we can describe accurately like we were there without leaving the classroom."
}

This finding is coherent with Rebelo et al (2012). They stated that the VR user can have an experience in VR environment and interact in in a safe manner even an environment with critical or dangerous condition. It is related when the participant in their research has to have interacts with hazardous product or environment that has a risk of injury through simulation. This finding also has same line with research from Dalgarno \& Lee(2010) which is stated that VR 
really helped the fire fighter in training on VR simulation practice. Firefighting on VR simulation provides a really safe and effective alternative rather than with real fire.

VR videos also help the students with movement problem such as students with special needs and with health problem. They said that even they have special needs and with health problem, they can learn normally as long as they do not have any neck problem because Google VR only require head movement or even not. When they used this standard VR gear, it requires very minimal movement. Student 10 stated:

\begin{abstract}
"Yes it helps people with limited movement. Now they can explore some place without worrying their limited movement because they are not leaving the classroom."
\end{abstract}

This finding also has same line with Gutiérrez et al. (2017). They stated that disabled students also can use VR technology and access Virtual environment. Furthermore, the students also agreed that VR video provides very accurate and authentic material for learning. They said that they learn very detail because they act like they can observed by themselves only by seeing $360^{\circ}$ in the video. Student 2 state related to this dimension.

\begin{abstract}
"As long as it is related. Also the material is really "real" and like we were observed it in real time, not by ordinary watching or even by reading a book."
\end{abstract}

This finding has same line with Rebelo et al. (2012). They said that Virtual environment provides the VR user a chance to collect data from Virtual environment with a high accuracy and a good ecological validity that not easily available in real-life setting. Also, the third factor is the reason that motivates students in learning English by using Virtual Reality as learning media is the students' answer is all towards the media itself. They motivated because it is new to them. They want to explore more with Google VR. It is new and not boring like conventional media. Student 2 states his opinion:

\begin{abstract}
"Yes of course. It is new for me and it is unique. I never learn this way before. It allows us to see $360^{\circ}$ like we were there. So I am excited in learning English with VR video."
\end{abstract}

This finding is coherent with the line from Gutiérrez et al. (2017) which state that virtual technologies increase student's motivation and engagement. It is because the students feel that they as a main character in VR video and it enhance their learning experience. This finding also supported by previous study from Yildrim (2018) which found that VR technology were motivating and compromising. The learner found that VR is enjoyable and effective and created a feeling of involvement. In addition, the last factor is from dimension about the students' opinion about using Virtual Reality as learning media as a tool of learning. All of them have positive answer toward this topic. This Google VR is an easy tool to use. After the researcher told them about the range price of Google VR, they have feeling that they want to buy Google VR for their own use. They think that it may help them learning at home and enhance their learning experience in learning English. Student 8 stated: 
"Of course it is an easy tool to use. It only requires phone with gyroscope and put in Google VR with video VR in it. Voila, it is ready to use"

This finding has line from Gutiérrez et al. (2017) which state that recent virtual technology is available in every gear such as smartphone, tablets and video devices. So, a complex gear is not required anymore to experience a Virtual Reality video.

\section{Weaknesses Dimension in Using Virtual Reality in the Classroom}

Even it had an effect toward experimental group, it had low effect size because from the two groups with the Cohen's d value that calculated from Standard Deviation is 0.9944and the Eta Squared value that determines the how far the Virtual Reality affects the Experiment group is 0.4452 . The VR treatment only affects $46.6 \%$ of the students' score. From the effect size table, the result has low impact on students' score.

This result is caused by some factors such as three dimensions consist of one response each from strengths and four dimensions is from weaknesses of using VR-English leaning based in the classroom. The first factor is come from weakness dimension about the students' opinion about the quality of the tools and the material in Virtual Reality in low-cost budget compared to a real highcost Virtual Reality gears with high quality tools and material. The result is some of the student feel okay with low budget because it required minimum preparation in terms of using it in big number of students in one classroom in term of the tools (in this case, Google VR). In the other hand, some of them argued that they have problem with the Google VR itself because the quality of the low-budget Google VR with standard features and also they feel like the quality of some video on YouTube is not too good and in some cases, the supporting gear such as school Wi-Fi, sometimes is not working. Also, some of the lens on low-budget Google VR is not clear. The last is the limited of Google VR. So, they needs time to pass the Google VR to other friends.

This finding has same line with Rebelo et al.(2012) which state that the higher the specification of the gear, better the quality of the material itself. Since the researcher conducts a low budget VR classroom, the students faces some challenge because the limitation of the budget. One of them is the researcher depends on the Wi-Fi but sometimes the Wi-Fi is not works properly so it makes the researcher difficult to conducting VR learning in the classroom. Other thing is the number of Google VR. Because the number of Google VR that used by the researcher is 8 units and used by 35 students, it is hard to let the students used it freely. This is the cause of the low effect size of the result of the researcher's quantitative research.

Second factor is from dimension that investigates the students if there is any negative effect (VRISE) toward their health aspect after using and while using Virtual Reality. Some of the student felt uncomfortable especially students with glasses and one of them felt dizzy after using VR in the classroom. This finding was supported by Rebelo et al.(2012) that one of the term that felt by the student is the motion sickness (ME). Rebelo et al. stated that motion sickness has symptom such as vomiting, nausea, eye disorientation as well as dizzy or postural instability. This finding also supported by Yildirim (2017) which is stated 
that the researcher found that five participants has dizziness after using VR videos.

Furthermore, the third factor is from dimensions about the students' opinion about the cost in conducting Virtual Reality learning. After the researcher told the student about the cost of all of meeting even with low cost, the students said that it is expensive. This finding is same line with Gandhi \& Patel(2018) which stated that cost is another challenge in conducting VR classroom because many small or medium scaled people cannot afford a VR technology to implement in a classroom.

The fourth factor is from dimension is to investigate the students about their difficulties in using Virtual Reality gears and its features. All of them said that the face same difficulties. First is how to use Google VR, even some of them encounter problems how to connect Wi-Fi to their phones because the school Wi-Fi is not working and also some of the students' phone is difficult to connect to school W-Fi. Also, the students encounter some problems in setting their phone in Virtual Reality mode because some of their phone is not supported for Virtual Reality. It takes time to learn to use it. This finding is coherent with Pantelidis (2009). She stated that the students need time to learn how to use the software and the hardware of VR technology.

Then, the fifth factor is from strength dimension that investigate the students about their opinion about using Virtual Reality as learning media in build their own understanding in learning English is some of student feel that Virtual Reality-learning based in learning English is really helping them building their own understanding because they feel excited. They excited because it gives them "real-life" experience. It helps them to think critically while they watching VR video. But some of them feel that they had no feedback since the VR-learning based is low budged and they only experiencing only $360^{\circ}$ movement without any hot point to interact with. This finding is contrast with the statement from Gutiérrez et al. (2017). They reported that Virtual technologies allow the students to learn in constructivist approach. They also stated that in Virtual technology, the student can freely interact and receive feedback on virtual object that improve the students' learning experience. It is contrast from the theory because the researcher uses the low budget Virtual technology that can only do a passive observation VR video. It is one of the factors that affect the experiment group that cause low impact on the effect size of the result on researcher's quantitative research.

The last factor is from strength dimensions in using VR-English leaning based in the classroom. Even though VR provides the students with real-life experience context, in fact, the student cannot access all "real-life" experience content. For instance, not all places in the world can be visited with VR. Some of the students argued that not all places can be visited such as rural area or not popular area in the world. Some of them also said that they could not visit all placed in the world especially on YouTube. Plus, the students found that some VR video on YouTube is not what they mean or fake. For example, they want to visit a beach on VR You Tube and the title is VR Video. The fact is that video is not in VR formatted video. Then, the second respond form strength about their opinion about using Virtual Reality as learning media in build their own understanding in learning English. In one of the question about the students' response about if their receive any feedback from VR videos, some of them felt that they have no feedback since the VR-English learning based is low budged 
and they only experiencing only $360^{\circ}$ movement without any hot point to interact with. They felt that they could not experience more because they were only watching VR videos passively. Those findings was contrast with the theories from strengths dimension that stated VR provides "real-life" learning context that help the students to learn deeply in new and immersive experience (Dolgunsöz et al., 2018; Dong, 2017; Pantelidis, 2009; Rebelo et al., 2012; Yildirim, 2017).

From the explanation above about the result of the present study, it showed that Virtual Reality-English learning activities is effective but with low effect for the tenth-grade students' English learning achievement in form or writing skill. The success of the experiment of the effect of VR-English learning activities is supported with the strengths and weaknesses that faced by students in the classroom. It can be referred as follow: Virtual Reality-Based learning activity is one of the learning media than can affect students' English learning achievement in the classroom.

\section{CONCLUSION}

Referring to the descriptive and inferential static analysis that already presented in previous chapter, it could be concluded that Virtual Reality-based English learning activity gave a slightly differences on students' English achievement. It could be seen on from inferential static analysis on the mean score between experimental group is higher than control group. The mean score of experimental group was 86.94 while the control group was 80.00. It was indicated that the students' English learning achievement in form of writing skill from experimental group was better than students from control group. In spite of had a positive result, the researcher also found that the effect of Virtual Realitybased English learning activity had a low size effect toward students' English learning achievement in form of writing skill on $10^{\text {th }}$ grade $A$ public secondary school in North Bali public secondary school in North Bali. This finding also supported by the result of the interview that conducted by the researcher.

The result of using Virtual Reality in the classroom was strengthen by the result of the mean score of experimental group meanwhile the result of weaknesses of using Virtual reality in the classroom is the cause of the low effect size of the effect of Virtual Reality-based English learning activity toward students' English learning achievement on $10^{\text {th }}$ grade A public secondary school in North Bali. In the end, the conclusion of this research Virtual Reality-based English learning achievement is one of other things that can be affect the students' English learning achievement in A public secondary school in North Bali especially in form of writing skill.

As following the result of this study for future matter, there are some suggestions which can be proposed by the researcher. It is recommended for English teacher to use Virtual Reality in the classroom in order to engage the students in learning process and also to explore more the other possibility material that can be used as learning sources. This learning method enables the teacher to give chance to the students to explore more about material and give them a real-life evidence related material to enhance their learning experience. In addition, the use of Virtual Reality in the classroom can make the learning session to more students centered and increase their critical thinking. For students, it is recommended to learn with this new integrated method of learning. It is typically new and makes the student more engage in the classroom rather than learning through conventional media such as text books and videos. For 
educational institution, it recommended to conduct a Virtual Reality supported learning class with its supported gears. It really important and needed because it provided the user the new futuristic learning that provide them with real-life evidence related material to enhance their learning experience. For other researcher wore are have interest in conducting a similar research, it is suggested to improve it by using a higher specification media such as Virtual Reality Google with Bluetooth controller or other similar devices to support the Virtual Reality passive user. It is also recommended to conducting a similar research to other population and larger area to gain more in depth evidence and analysis about the strength and weaknesses of using Virtual Reality on education. Also, it recommended to try on different material and skill (other than descriptive text, writing skill, and others) and other subject (science, math, history and others).

\section{REFERENCES}

Creswell, J. W. (2014). Research design: Qualitative, quantitative, and mixed methods approaches (4th ed.). California: SAGE Publications, Inc.

Dalgarno, B., \& Lee, M. J. W. (2010). What are the learning affordances of 3-D Virtual environments? British Journal of Educational Technology, 40(6), 10-32. https://doi.org/10.1111/j.1467-8535.2009.01038.x

Dolgunsöz, E., Yıldırım, G., \& Yıldırım, S. (2018). The effect of virtual reality on EFL writing performance. Journal of Language and Linguistic Studies, 14(1), 278-292.

Dong, X. (2017). An overall solution of Virtual Reality Classroom, (October). https://doi.org/10.1109/SOLI.2016.7551672

Gandhi, R. D., \& Patel, D. S. (2018). Virtual reality - opportunities and challenges. International Research Journal of Engineering and Technology (IRJET), 5(1), 482-490.

Gutiérrez, J. M., \& Mora, C. E. (2017). Virtual technologies trends in education, 8223(2), 469-486. https://doi.org/10.12973/eurasia.2017.00626a

Müller, J. M., Kiel, D., \& Voigt, K. (2018). What Drives the Implementation of Industry 4 . 0 ? The Role of Opportunities and Challeng es in the Context of Sustainability. Susainability, 10(247), 1-24. https://doi.org/10.3390/su10010247

Pantelidis, V. S. (2009). Reasons to Use Virtual Reality in Education and Training Courses and a Model to Determine When to Use Virtual Reality. Science And Technology Education, 2(1-2), 59-70.

Park, H. S. (2017). Technology convergence, open innovation, and dynamic economy. Journal of Open Innovation: Technology, Market, and Complexity, 3(24), 1-13. https://doi.org/10.1186/s40852-017-0074-z

Piovesan, S. D., Passerino, L. M., \& Pereira, A. S. (2012). Virtual reality as a tool in the education, (Celda), 295-298.

Rebelo, F., Noriega, P., Duarte, E., \& Soares, M. (2012). Using Virtual Reality to Assess User Experience. Human Factor: The Journal of The HUman Factors and Ergonomics Society, $X X(\mathrm{X}), \quad 19$. https://doi.org/10.1177/0018720812465006

Santosa, M. H. (2017). Learning approaches of Indonesian EFL Gen Z students in a Flipped Learning context of Indonesian EFL Gen Z students. Journal on English as a Foreign Language Learning Approaches, 7(2), 183-2018. 
The Art of Teaching English as a Foreign Language, Vol.1 No.2 2020

p-ISSN : 2656-8942, e-ISSN : 2684-8546

DOI: $10.36663 /$ tatefl.v1i2.88

https://doi.org/10.23971/jefl.v7i2.689

Törőcsik, M., Szűcs, K., \& Kehl, D. (2014). How Generations Think : Research on Generation Z. Acta Universitatis Sapientiae, Communicatio, 1, 23-45.

Yildirim, G. (2017). The Users' Views on Different Types of Instructional Materials Provided in Virtual Reality Technologies. European Journal of Education Studies, 3(11). https://doi.org/10.5281/zenodo.1045349

Yildirim, G. (2018). Analysis of Use of Virtual Reality Technologies in History Education: $\quad \mathrm{A} \quad$ Case Study, 4(2), 62-69. https://doi.org/10.20448/journal.522.2018.42.62.69 